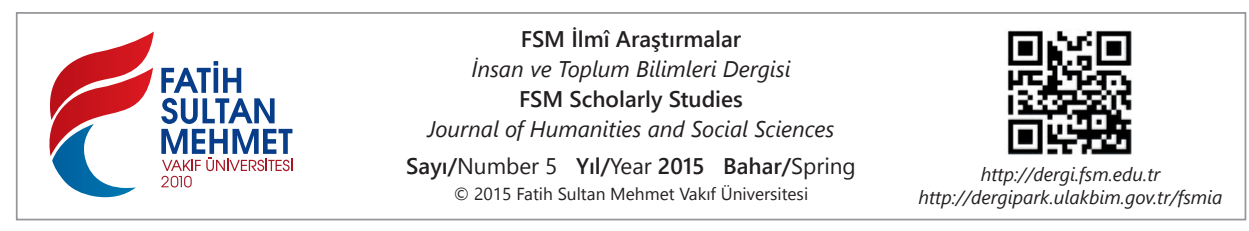

\title{
Ütopyadan Doğmak, Ütopya Doğurmak: Heterotopya Kavramı ve Heterotopya Bağlamında Balık Izlerinin Sesi
}

Gülsün Nakıboğlu*

\section{Özet}

Heterotopyalar modernite bağlamında ütopyaların hayata geçirilme girişimlerinin doğal bir sonucu olarak değişme ve gelişme eğilimi gösterirler. Heterotopya kavramsal olarak her zaman ütopya ile yakından ilişkilidir. Buket Uzuner'in Balık İzlerinin Sesi romanı daha önce yapılan çalışmalarda çoğunlukla romanın sonunda anlatılan ütopya adası açısından değerlendirilmiştir. Bu makalede roman bütünüyle incelenmekte, ütopyadan doğan ve ütopya doğuran bir heterotopyanın anlatımı olarak ele alınmaktadır.

Anahtar Kelimeler: Ben, öteki, ben-öteki diyalektĭgi, normalleştirme, heterotopya, ütopya, distopya, roman, panoptikon, süper-panoptikon, sinoptikon.

\section{To be Created from an Utopia, to Procreate an Utopia: Concept of Heterotopia and Balık Izlerinin Sesi in Terms of Heterotopia}

\section{Abstract}

Heterotopias, at modernity context, show changing and developing tendecy as a natural result of being embodied attempts to utopias. Conceptually heterotopia is always related utopias intimately. At previously studies about Buket Uzuner's Balık Izlerinin Sesi, novel is mostly regarded in terms of utopian island which is being uttered at the end of the novel. İn this study novel is discussing totally and it is reviewed as an utterance of a heterotopia which is created from an utopia and is procreated an utopia.

Keywords: I, other, I-other dialectic, normalizing, heterotopia, utopia, distopia, novel, panopticon, super-panopticon, synopticon.

* Dr., İstanbul Teknik Üniversitesi, Türk Dili Bölümü, İstanbul/Türkiye, gulsunnakip@yahoo.com 


\section{Heterotopya Kavramı ve Kavrama Dair Bazı Dikkatler}

Ben-öteki ilişkisi kadar mekân-insan ilişkisinin de modernite bağlamında değişmeye başladığını fark eden yakın dönem kimi düşünürlerinin bu iki ilişki türünü beraberce değerlendirebilecekleri mekânlar olarak heterotopyaları anlama ve anlamlandırma noktasında çeşitli eserler verdikleri görülmektedir. Heterotopyalar, sadece birer mekân olmayıp insanın insanla ilişkisinin günümüz dünyasında nasıl şekillendiğini gösteren örnekler olarak önem arz etmektedirler.

Parçalara ayrılan bir bütünün, parçaları önem kazandıkça bütünlüğü unutulmaya başlanmakta, parçalar arasındaki ilişkinin önceki bütünlükten uzaklaştırılarak algılanma eğiliminin kuvvetlenmesi neticesinde söz konusu algının bütünlüğü geri dönülmez bir hâle getirilmekte ve genel olarak parçalar arasındaki ilişkinin benzerlik ilişkilerinden çok karşıtlık ilişkileri üzerinden anlaşılmaya müsait mutabakatlara tevili söz konusu olmaktadır. İnsanın parçalamaktaki, adlandırmaktaki, sınıflandırmaktaki maharetini mekân üzerinde de sürdürdüğü görülmektedir. Tüm parçalara ayırma tecrübeleri yine de bütünlügü ortadan kaldıramamakta, düşüncenin somutlandığı en önemli insanî araç olarak dilde her iki anlam yan yana bulunmaktadır. Arapça "kevn" ("olma" ve "var olma, varlık, vücut" anlamlarına gelmektedir') kökünden gelen "mekân" kelimesinde de aynı anlamlar içkindir. Mekân hem "yer, mahal" hem de "ev, oturulan yer" anlamlarına gelerek bütün ve bütünden ayrılan parça anlamlarını bünyesinde beraberce taşımaktadır.

Bir bütün olarak, esas mekân mahiyetiyle dünyanın parçalara ayrılması s1nırların söz konusu olmasıyla mümkün olur. Sınırların dışı ile içinin arasındaki farkın belirginleştirilmesiyle bütünden ayrılan/ayrıldığı zannolunan parçanın soyutlama, sırlama, saklama, gizleme vasıflarıyla donatılmaya başlandığı görülür. $\mathrm{Bu}$ temel yaklaşım sınırlamanın ve sınırlandırmanın sadece yatay düzlemde değil her üç boyutta da deneyimlenmesiyle diş ve iç arasındaki temel farkın ortaya çıkışııı hazırlar. Mekândaki bölünme ve iç-dış algısının ortaya çıkışı zamansal algılardaki farklılıkları da peşi sıra getirmekte, içteki bölünmüş mekâna iyelik hakkı bir kavram olarak gün yüzüne çıkmakta ve iyelik hakları esasına dayanan yeni bir haklar manzumesi silsilesinin başlangıcına işaret etmektedir. Söz konusu haklar ile iç ve dış arasındaki bölünmüşlük hâli insan yaşamını, insanın zamanı ve mekânı kavrayışını da doğrudan etkilemektedir. Tüm bu iç-dış bağlamında kazanılan tecrübelerde esasen insanın parçalardan ibaret ve parçalayarak, bölerek, ayırarak algılama temayülü tebarüz etmekte ve düşünceden başlayarak kişinin her türlü tecrübeye dayanan faaliyetlerine de temas ve etki eden bir tür gerçeklik zannını peşi sıra getirmektedir. Bu türlü kavrayış insana kapattığı, kendine

1 Ferit Devellioğlu, Osmanlıca-Türkçe Ansiklopedik Lûgat: Eski ve Yeni Harflerle, 10. Bs., Ank., Aydın Kitabevi, 1992, s. 614.

2 A.e., s. 721. 
ayırdığı ve "iç" ile tanımladığı iyelik parçası ile açık (kapalıyı çevreleyen ve kapatan anlamıyla nitelemenin tam tersi bir anlamı da taşıyarak) ve iyesi olmadığ “dış" parça arasında bir taşıyıcılık vasfı da yüklemektedir. Jean Hyppolite'e göre bir tür yabancılaşmanın kanıtı olan iç-dış diyalektiği bağlamında her bir kutbun karşıtlığ yanında düşmanlığının da göz ardı edilmemesi gerekmektedir. ${ }^{3}$ İç ile dış karşıtlığ gibi algılanan durum aslında birbirini tamamlayan unsurların zıtlık bağlamında ele alınışıyla ilgili olup mütemmim cüzün karakteristik vasfinın elinden alınmak ve tümleyeniyle zıt kutuplara yerleştirilmek suretiyle aslından ayrılmasına, koparılmasına, uzaklaştırılmasına bağlıdır. Söz konusu görece iyelik zannının insanı kendi içinde de kapanmaya, parçalanmaya sevkiyle insan kendi ayırıp parçaladığı ve genel olarak iç-dış şeklinde nitelendirdiği mekânın dolay11 yoldan tanımladığını varsaydığı bu taşıyıcılık vasfina aldanarak parçalanmış mekânın kendisine sunduğunu kabul ettiği mecburiyetleri düşünerek geliştirdiği yaşam kuralları ve sistemleri belirlemekte; sistemin kapatma, sınırlama ile doğrudan ilişkisi her zaman öne çıkmaktadır. Bireyin iyelik hakkı talebi sınırladığ 1 'iç' ile sınırlı kalmamakta kimi zaman da içselleştirmeye (kendi tanımladığı 'iç'e almaya, katmaya) çalıştığı nesneye ve hatta insana dahi yönelebilmektedir.

İnsanın mekân üzerinde sahip olduğuna inandığı iyelik hakkı, kapatma-kapanma pratikleri şeklinde gelişmektedir. Kişi sahip olduğuna inandığı, kapattı̆̆1 ve 'kapalı' olarak nitelendirdiği mekânı ya kendisi kapanmak ya da öteki olarak nitelendirdiklerini kapatmak için kullanmaktadır. Kapanma-kapatma pratikleri; sınırlı ve kapalı olan mekân ile ilişkinin esasını teşkil etmekte, insan düşüncesinde ve eylemlerinde kuşatıc1, kapsayıcı bir rol üstlenmektedir. İnsan kapand1ğ1 mekânda kendisini her türlü nazardan uzakta, koruma altında hissederek bu mekânı ötekilere yasaklamaktadır. Kapatma pratikleri ise farklı ve daha karmaşık bir yapıda tezahür etmekte; öteki'ni kapattığı mekânla bağlantısı kişinin iyelik ilişkisiyle belirlenmekte ve kişi öteki'ni kapatırken kendisini de kavramsal olarak aynı mekâna bağlanmaktan, dolaylı yoldan kapatmaktan alıkoyamamaktadır. Dolayısıyla öteki'ne yasaklanan kapanma mekânı ile öteki için hazırlanan ancak ben'in dolaylı yoldan kendini de bağladığı/kapattığı kapatma mekânı temel bir farklılık içermektedir. Gerek kapanılan gerekse kapatılan mekân ben'in ortak kapanma mekânı iken öteki'ne tahsis edilen tek kapalı mekân şekli kapatma mekânı olmaktadır. Ayrıca kapanılan mekân yalnızca öteki'nden korunmak için cebri meşru kılabilirken, kapatılan mekân öteki'ne bizatihi uygulanan her türlü cebri meşrulaştırmaktadır. Ben'in bedeninin etrafını saran ve onu kuşatan kapanma mekânıyla öteki'nin bedenini kuşatmak (sahip olmak anlamıyla da) üzere oluşturulan kapatma mekânı bedenle ilişkisi bağlamında da farklılık arz etmekte-

3 Jean Hyppolite, "Commentaire parlé sur la Verneinung de Freud", La psychanalyse, no:1, 1956, s. 35’ten aktaran: Gaston Bachelard, Mekânın Poetikası, Çev. Alp Tümertekin, İst., İthaki Yay., 3. Bs., 2013, s. 256. 
dir. Öteki'nin bedenine tahakküm kişinin kendisinde deneyimlediği kapanmaya dair tecrübelerini farkl1laştırarak yansıttığ 1 , ben'e özgü ve bağlı kılmaya çalıştığ 1 öteki'nin bedenini doğrudan hedef alan bir dizi yaklaşımın da doğmasına sebep olmaktadır.

Kapanma-kapatma pratiklerinin geçmişi insanlık tarihinin çok eski dönemlerine kadar uzanmaktadır. Modernite dairesinde, gelenek dairesindeki tecrübeye dayanan bilgiyi bağlı olduğu köklerden kopararak ya da diyalektik açıdan zıddını üretme yoluyla ortadan kaldırarak veyahut amaçları doğrultusunda değiştirerek kullanma edimlerinin öne çıktığı kabul edilecek olursa söz konusu kapanma-kapatma pratiklerinin moderniteyle değişimini takip mümkün olabilmekte aksine bir yaklaşım yeni ve köksüz bir yapı olarak değerlendirilecek söz konusu pratiklerin mahiyetinin, ortaya çıkış sebeplerinin kavranmasını zorlaştırmaktadır. $\mathrm{Bu}$ bağlamda Michel Foucault, kapanma ve kapatma mekânlarını farklı bir açıdan ve modernite-gelenek bağlamında tartışırken 'heterotopya' kavramından faydalanır.

Esasen bir anatomi terimi olan "heterotopia", bir organın ya da dokunun bulunması gereken yerde bulunmamas1 ya da farklı bir yerde bulunması anlamına gelmektedir. ${ }^{4}$ Homojen mekân algısının bozulmasına sebep olan kapalı mekân türlerinden bazılarının diğerlerine nispetle mevkilendirme ilişkileri bağlamında farklılaştığını ileri süren Foucault'ya göre insanı "kendi dışı[n]a çeken"; insan yaşamını, zamanı ve tarihi "erozyona uğra[tan]"; insanı "kemiren ve aşındıran" heterojen mekânları: Kriz heterotopyaları ve sapma heterotopyaları olarak adlandırmak mümkündür. ${ }^{5}$ Foucault'nun heterotopyalar bağlamında kapanma ve kapatma pratiklerine dayanan mekânları ayırdığı ve genel olarak modernitenin öne çıkardığı, sistemli kıldığg kapatma mekânlarına odaklandığ 1 görülmektedir. Kriz heterotopyaları olarak Foucault geleneksel topluluklardaki öteki'lere yasaklı mekânlar olarak kutsal ya da yasak mekânlardan bahseder. ${ }^{6}$ Foucault'nun kriz heterotopyaları olarak adlandırdığı kapalı mekânların karakterlerinin tespiti noktasında; bu tür mekânların öteki’leri kapatma gibi bir işlevi olmadığından 'kapanma' pratikleri bağlamında değerlendirilmesi daha doğru görünmektedir. Buradan hareketle gelenek dairesindeki kapalı mekânların çoğunlukla 'kapanma' ağırlıklı olduğu tespitini yapmak da mümkündür. Foucault, günümüz dünyasında kriz heterotopyalarının yerini sapma heterotopyalarının almakta olduğunu ve sapma heterotopyalarının normal kabul edilenden ayrılan, doğru yoldan sapan kişilerin normalleştirilmek, doğru yola döndürülmek üzere yerleştirildikleri mekânlar olduğuna inanır. ${ }^{7}$ Foucault'nun sapma heterotopyaları bağlamında ele

4 http://medical-dictionary.thefreedictionary.com/heterotopia (27.12.2014)

5 Michel Foucault, "Başka Mekânlara Dair", Özne ve İktidar: Seçme Yazılar, İst., Ayrıntı Yay., 2011, s. 293-294, 296-297.

6 A.e., s. 296.

7 A.e., s. 297. 
aldığı hapishane, akıl hastanesi, huzurevi gibi kurumların genel olarak 'kapatma' pratiklerinin sistemleştirildiği kurumlar olduğu görülmektedir.

Moderniteyle birlikte 'kapanma' pratiklerinin sona erdiğini söylemek ise mümkün değildir. Değişmiş, gelişmiş, dönüşmüş ama var olmaya devam etmişlerdir. Örneğin ev; insanın ünsiyet kurduğu, benliğini yansıttığı bir aynayı andıran, dışarıdakilere sırlı bir kapalı mekân olarak 'kapanma' işlevini sürdürmektedir. Toplumsal yapının ve sosyal organizasyonun gelişmesiyle birlikte görünüşte kapalı olsalar da herkesin ortak kullanımına açık mekânların sayısı gittikçe artmış ancak söz konusu mekânların görece tüm halka açık olmaktan kaynaklanan ve 'açık' mekânları taklit eden yapısı kısmen de olsa zamanla bozulmalara uğramaya başlamıştır. Ötekilere kapatma, süreç içerisinde ötekileri kapatmaya dayalı bir anlayışa yerini bırakmıştır. Bu tür görece açık mekânlardaki sınırlamalar da başlangıçta öteki'ni dışarıda tutan yapısı itibariyle daha çok 'kapanma' pratiklerini taklit eden bir yapı özelliği sergilemekte ancak öteki' ne tahakkümün, öteki üstünde hak iddiasının 'kapatma hakkı' olarak görülmeye başlanması ve bu yaklaşımın geliştirilerek bir sistem hâline getirilmesiyle bahsi geçen kamuya açık mekânlar sadece kapanma pratiklerinin değil kapatma pratiklerinin de uygulandığı mekânlar hâline getirilmişlerdir.

Kapatmanın sistemli bir hâl alışı ve kendi iç sistemini hıla geliştirmeyi başarmas1, öteki'ne yönelik tarih boyunca geliştirilen tüm okuma biçimlerinin de değişmesini gerekli kılmaktadır. Nitekim ben-öteki ilişkisine dair yaklaşımlar moderniteyle birlikte farklılaşır. Söz konusu ilişki üzerine pek çok teori ortaya atılır ve öteki, ben'in üzerinden kendisini tanımlamak zorunda olduğu nesne konumuna getirilirken ben ile ötekinin bağl1lığı sürekli vurgulanır ve bu ikili yapının parçalı, içte sürekli çatışan bir temel çatı olarak kabulü sağlanır. Üretilen tüm felsefî yaklaşımlar eninde sonunda bir ‘öteki’nin varlığının kabulüne ve merkezdeki 'ben'in yerinin güçlendirilmesine hizmet etmektedir. Foucault söz konusu bu değişimin sebeplerinin ve nasıl gerçekleştiğinin heterotopyaların genel karakterinin incelenmesiyle ortaya konulabileceği iddiasıyla heterotopyaların başat özelliklerini tespite çalışır. Foucault, heterotopyaların işlevlerinin zaman içinde değişebileceğini; heterotopyaların bağdaşmaz, bir araya getirilemez kabul edilen mekânları bir araya getirme özelliği taşıdıklarını; "heterokroni" olarak adlandırllabilecek bir zaman bölünmesine işaret ettiklerini (zamanın biriktirildiği müze ve kütüphanelerle onların zıddına zamana bağlı olarak kronik bir şekilde şenlik, karnaval, panayır gibi sürekli tekrarlanan ancak mekânsal daimiliği söz konusu olmayan kronik heterotopyalar bu sınıfa girerler); daima bir açılıp kapanma sistemine ihtiyaç duyduklarını (kapıları herkese açık olmayan ve öteki olanların bir tür zorlamayla kalmak zorunda bırakıldıkları, çeşitli "arınma" ve "kurallara boyun eğme" zorunluluğunun mutlaka bulunduğu mekânlardır) ve çevrelerinde yer alan diğer mekânlarla girdikleri rekabette bir tür yanılsamaya sebep olduklarını 
belirtir. ${ }^{8}$ Heterotopyaları, Foucault'nun tespitlerinden hareketle birer "kapatma" mekânı olarak "kapanma" mekânlarıyla yarıştı̆̆ını söylemek mümkündür. Hatta açık mekânlara benzer hüviyetteki kapanma mekânları da bugün gittikçe gönüllü kapatma mekânları hâlini almaktadır. Baudrillard'ın simülakrlar bağlamında ele aldığ 1 alışveriş ya da büyük eğlence merkezleri ${ }^{9}$ de kapatma pratiklerini taklit eden ve gönüllü kapatmayı esas alan bir noktada durmaktadırlar. Zorunlu kapatma mekânları olarak bedeni ve zihni ele geçirmeye çalışan hapishane, akıl hastanesi, huzurevi gibi kurumlarla; zihnin, duyguların, özellikle hazzın ve bedenin kontrolünü amaçlayan gönüllü kapatma mekânları olarak alışveriş merkezleri ya da eğlence merkezleri arasındaki kapatma pratikleri noktasındaki benzerlik ve münasebet aşikârdır. Gönüllü ya da gönülsüz kapatma sistemi benzer dinamikleri içermekte ve gittikçe her bir heterotopyanın kendi içinde işleyen sisteminin, sistemlerin ortaya çıkış noktasının benzerliği ve sistemlerin yakınlığı nispetinde birbirine dönüşme eğilimi gösterdiği anlaşılmaktadır. Ben'in öteki üzerinde kapatma hakkına sahip olduğu savının ve öteki'ni ben'e dönüştürme eğiliminin baskın karakterli ben'leştirici, ben'i kendi gücüne inandırmaya yönelik tutumunun sonucu olarak ben'in kendi gücünü arttırıcı söylemlerle, kendisini yönlendirmeye hazır modern anlatılarla (belki meta-anlatılar) ikna edişinin ilk örnekleri olması hasebiyle gönülsüz kapatma pratiklerinin sistemleştirildiği mekânlar olarak hapishane, akıl hastanesi, huzurevi benzeri kurumlar heterotopyaların iç sisteminin öteki'ne tahakkümle yüceltilmek istenen ben'e dayanan egemen karakterinin anlaşılmasını kolaylaştırmaktadır.

Heterotopyalar birer kapatma mekânı olarak kendi dışındaki tüm mekânı bir kara delik gibi sürekli kendilerine çekip kopyalayarak, bozarak yutma eğilimindedirler. Bir hapishanenin koğuşları, bir akıl hastanesinin ya da huzurevinin odaları kapanma mekânı olarak nitelendirilen evin bozulmuş birer kopyası olarak heterotopya içinde kapatma mekânına dönüştürülerek yinelenmektedir. $\mathrm{Bu}$ kurumlar içindeki çamaşırhane, mutfak, yemekhane, dinlenme salonları; benzeri şekilde kapanma mekânlarının bozuk birer kopyası iken heterotopyalar bir taraftan da toplumun tamamına açık oluşlarıyla 'açık' mekânları taklit eden park gibi mekânları da esasından uzaklaştırarak kopyalamak suretiyle bünyelerine katmakta hastane, kütüphane gibi farklı heterotopyaları da bünyelerine dâhil ederek gittikçe daha karmaşık birer sistemli kapatma mekânı hâlini almaktadırlar.

Heterojen mekân algısının sonucu olarak gösterilen heterotopyalar yayılma, gelişme ve geniş̧leme eğilimindedirler. Heterojenin homojenleştirme, kendine dönüştürme, ele geçirme, bozma, yutma kapasitesi genelde bu bağlamda yadsın-

8 A.e., s. 297-301.

9 Jean Baudrillard, Simülakrlar ve Simülasyon, Çev. Oğuz Adanır, 6. Bs., Ank., Doğu Batı Yay., 2011, ss. 30, 111-127. 
makta; ötekilerin sayısı, çeşidi, nitelendirilme biçimleri arttıkça ben'in karşısına çıkan her bir öteki'nin taklidî bir kapatma pratiğine tâbi tutulmaya başlandığı göz ard 1 edilmektedir. Heterotopyaların yayılma ve homojenleştirme, kendileştirme eğilimi ile karakteristik özelliklerinin toplumsal hafızaya sirayeti öteki’nin ben'e tabiiyetini bilinçaltına itmekte ve fark edilmeden kabullenilişini, içselleştirilmesini sağlamaktadır.

Heterotopyaların yayılma eğilimini ve kapasitesini en kolay takip etme yolu 'panoptikon'un günümüz dünyasındaki yaygınlaşmış, kabullenilmiş, benimsenmiş yapısıdır. Ben'in öteki’ni kapatmak üzere keşif ve inşa ettiği kapatma mekânına -ben bunu kabullenmek istemese de- öteki'yle birlikte kendisini de yerleştirme, öteki'ni görme ve eksiksiz gözetleme ancak öteki'nin nazarından korunma böylece dâhil olduğu kapatma mekânında varlığını kesinleştirip, bakışını keskinleştirirken varken yok, yokken var izlenimi oluşturma idealinin somutlandığı bir mimari biçim olan "Panoptikon" Jeremy Bentham tarafindan tanıtılır. Bentham, bir İngiliz gazetesinde gördüğ̈ bir hapishane tasarımı üzerine İngiliz bir dostuna Beyaz Rusya'dan gönderdiği 1787 tarihli mektubunda ağabeyinin tasarladığ 1 ancak inşaatının çıkan 93 Harbi sebebiyle gerçekleştirilemediğini belirttiği özel bir gözetim evi modelinden bahseder. Bentham bahsi geçen mektubunda, yapay ve tüm çevreyi gören bir göz olarak ifadelendirilebilecek merkezî bir kulenin etrafına belli bir mesafede inşa edilen kapatma mekânı sistemi fikrini somutlaştırırken birbirinden ayrı küçük kapatma kutucuklarının/ hücrelerinin birbirlerini görmelerine mani olacak bir düzen dâhilinde üst üste ve yan yana istiflenmesiyle oluşan ve yapay gözü temsil eden merkezdeki kulenin etrafını çepeçevre saran yapı fikrini uzun uzun anlatır. ${ }^{10}$ Ben, bu kapatma sisteminde yapay gözün göremediği tek yere yerleştirilmektedir: yapay gözün içine. Bu merkez ben'in kendisiyle yüzleşmekten kaçınmak için geliştirdiği bir kapanma merkezi işlevi görmekte dolayısıyla heterojen mekân olan heterotopyanın merkezine modernite dairesinde ben'in yerleştirildiği sistemi aynen tekrarlayan bir kule mevzilendirilirken heterotopya kendi içinde kapanma ve kapatma pratiklerinin beraberce yer alacağı karmaşık bir yapı özelliğine büründürülmektedir. Merkezdeki kule çoğunlukla hegzagonal bir yapıya sahip olmakta ve görüş alanını genişletmeyi hedefleyecek şekilde planlanmaktadır. Ben bu sistemle bir taraftan öteki'ni gözetleme hakkını yatay düzlemde sonuna kadar genişletir ve kullanırken öteki'nin bakışından kaçma şansına sahip olmakta bir taraftan da ben'in kendi nazarından kaçma eğilimi de fark edilmeden bir tarafta durmaktadır. Mimari yapı öteki'nin ben'i görmesine engel olacak bir şekilde inşa edildiğinden merkezdeki yapay gözün varlığı öteki'ne ben orada olmasa da olduğu zannını vermekte ve gücü dairesinde bulunduğu ben'e sürekli bağlı olduğunu ona ha-

10 Jeremy Bentham vd., Panoptikon: Gözün İktidarı, Çev. Barış Çoban ve Zeynep Özarslan, İst., Su Yay., 2008, ss. 14-15. 
tırlatıp kabullendirmektedir. Foucault, her bir hücreye yerleştirilecek ve ben'in gözetimiyle hapsedilecek öteki'ler arasında deli, hasta, mahkûm, işçi ya da okul çocuğunun yer alabileceğini ${ }^{11}$ ve Bentham'ın panoptikonu keşfiyle modernite dairesinde öteki'ni işaretleme deneyimlerinin akabinde ortaya çıkan farklı bir sürecin sistemleştirilmeye başlandığını belirtir. ${ }^{12}$ Öteki'yle uğraşan ben böylece kendisiyle uğraşamamakta, öteki’ni gözlerken kendini görmek zorunda kalmamaktadır, kısacası bir heterotopya ben'in kendisiyle yüzleşme yükümlülüklerini, öteki'ne yansıtarak kurtulmaya çalıştığı bir sistem oluşturmaktadır. Öteki, ben'le yüzleşmeye (asıl beklenen kişinin kendisiyle yüzleşmesidir) ve ben'e benzemeye zorlanırken ben'in kendisiyle yüzleşmekten korkakça kaçışı sistemin aslında yüzleşmeye değil, öteki'ni sun'î yüzleşmelerle oyalamaya dayandığını açık eder. Aslında ortada gerçek anlamda bir yüzleşme, vicdanıyla karşı karşıya gelme, hastalığını ya da suçunu anlama ve kabul etme gibi bir amaç yoktur. Bu süreçte Foucault'ya göre önceki dönem hapishane benzeri kapatma yerlerindeki öteki’ni gözden rrak kılmak gayesiyle şekillenen sistemin aksine öteki'ni göz önünde bulundurma esasına dayanan yeni bir sistem ortaya çıkmaktadır. ${ }^{13}$ Göz önünde bulunduran, tutan ise ben olmaktadır. Foucault'nun söylediklerinden hareketle yukarıda ben-öteki ilişkisinin bir ayağı olarak kapatma mekânları hakkında söylenenlere ilaveten ben'in bu yeni tip kapatma mekânlarına kendisini katmasıyla, öteki'ni kendisini ve gücünü tasdikletebileceği bir konumda bulundurarak ben'ini inşa etme sürecine geçtiğini ve böylece ben'in öteki'ni kendi gözetim sınırları dâhiline çekerek yeni bir sistemde kimlik inşasını başlatmak suretiyle kendisini öteki'ne bağlamakta olduğunu, kendisinin öteki'ne bağımlılığının ise dolaylı olarak kapatarak gözetleyebildiği nispette arttığını tespit etmek gerekir. Ben'in sürekli gözetlediği öteki'ne dönüşme eğilimi, ayrıca üzerinde durulması gereken önemli bir noktadır. Öteki'ni gözetim altında tutarken kendi içinde bölünen ben'in, öteki'ni içselleştirmesi esasen ben'in homojen olduğu varsayılan bir mekânın önce öteki tespitiyle heterojen bir bölünmeye gitmesinin ardından öteki'nin ben'e dönüşmesi değil ben'in öteki'ne dönüşmeye başlaması beklenir. Foucault ise ben'in bu dönüşümün önüne geçmek için öteki'ni ben'e dönüştür-

11 Jeremy Bentham, panoptik sistemin kullanılabileceği alanları şöyle anlatır: "Amacın dışında olması ya da amaçlanana ters düşmesi önemli değil; bina, endüstrinin her alanındaki iş kollarındaki sslah edilmeyenlerin cezalandırılması, delilerin denetim altında tutulması, ahlaksızların ıslah edilmesi, şüphelilerin hapsedilmesi, tembellerin çalıştırılması, acizlerin bakılması, hastaların tedavi edilmesi, gönüllülerin yönlendirilmesi, ya da eğitim alanında yeni neslin eğitilmesinde olsun: tek kelimeyle, ölüm odalarında hükümlülerin kaldığı cezaevlerinin ya da yargılanma öncesi sanıkların tutulduğu nezarethanelerin ya da azılı suçluların kaldığı hapishanelerin, ya da islahevlerinin ya da düşkünlerevlerinin, ya da imalathanelerin, ya da akıl hastanesinin, ya da okulların amaçlarına uygulanabilir." A.e., s. 12.

12 Michel Foucault, Hapishanenin Doğuşu: Gözetim Altında Tutmak ve Cezalandırmak, Çev. Mehmet Ali Kilıçbay, 5. Bs., Ank., İmge Kitabevi, 2013, s. 295.

13 A.e., s. 296. 
me idealiyle ben'in kurduğu sistemin inşasındaki gizli ve asıl idealin zaten öteki'ni hiçbir zaman ben'e dönüştürmemek olduğu kanaatindedir. ${ }^{14}$ Böylece ben, her zaman öteki ile arasındaki öteki'ne dönüşümünün önüne geçecek güvenli mesafeyi korumaktadır. Ortak idealin söylemle işlevdeki zıtlığı, heterojen yapının çelişkili karakterinin öteki'ni sevk ettiği karmaşa; öteki için baş döndürücü bir kaçış eylemi hazırlamaktadır. Öteki hiçbir zaman dönüşemeyeceği, kendisini gözetleyen ama göremediği merkezdeki ben'i tanrılaştırmakla ondan nefret etmek arasındaki gelgitli deltada yol almaya çalışırken yapabileceği yegâne eylem klasik mantık kuralları çerçevesinde bir şeye hem var hem de yok diyen sistemin dışına çıkmaya gayret göstermektir. Sistemin dışına çıkma yollarından biri de ütopyalar düşlemektir.

Panoptikon sistemi moderniteyle birlikte gelişmiş, ben'in güç pratikleri dâhilinde kurgulanmış ve sistemleştirilerek içselleştirilmiştir. Bauman günümüzde aynı sistemin siber dünyaya "süper-panoptikon" nitelemesiyle taşınırken gönüllü gözetlenenler oluşturduğunu ancak bu dünyada öteki'lerin panoptik sistemdekiler yerine sistemin dışında bırakıldığını yani kapatma sisteminin dışına itildiklerini ve sistemin yeniden kapanma pratiklerine geri döndügünü ima eder. ${ }^{15}$ Bauman'ın atladığı nokta 'ben' nitelemesi içerisine dâhil edilenlerin panoptikonun merkezine yerleşmeye ve orada yığılmaya başladıklarıdır. Sinoptikon adı verilen ve öteki'nin ben'i gözetlemesine dayanan sistem ise öteki'nin konumunu yeniden tartışmalı hâle getirmekte öteki'nin gönüllü gözetleyiciliği ya da beklenir röntgenciliği neticesinde gördükleri asıl görmesi gerekenlerin önüne indirilen bir perdedeki seyirlik gösterilerden ibaret kalmakta yani sadece panoptikonun mevcut varlığının rahatsızlık verici görüntüsü, onun merkezdeki varlığg unutturulmaksızın önüne indirilen bir perdeyle sevimli kılınmaya çalışılmakta, ben yine görünür olmamakta, kendisi adına simgesel görüntüyü temsilen seçtiği (kulenin yerine) kuklaların gösterilerinin sergilendiği perde ardında görünür görünmezliğinin devamını sağlamakta ancak sistem daha da karmaşık bir hâl almaktadır. Sistemin karmaşıklaşma sebepleri öteki'nin de ben'in de yüzleşmeden uzak tutulmaya başlamalarıdır, öteki artık zorla değil gönüllü olarak gözetlenmek istemektedir. Ben'in kendisini gönüllü olarak kapattığ1 (kapandığını sandığı) merkez kuleyle öteki'nin gönüllü olarak kapandığını sandığg (kapatıldığını unuttuğu) çevre, kapanma-kapatma pratikleri açısından yeni bir evreye geçildiğini gösterir. Bu evrede heterotopya içinde merkezin yanıltıcı vasfının tüm yapıya sirayet ettiği ve bu açıdan bir homojenleşmenin söz konusu olmaya başladığı anlaşılmaktadır.

14 A.e., s. 386.

15 Zygmunt Bauman, Küreselleşme: Toplumsal Sonuçları, Çev. Abdullah Yı1maz, 5. Bs., İst., Ayrint1 Yay., 2014, s. 59-60. 
Heterotopyaların ve heterotopyaya özgü panoptik sistemlerin George Orwell'ın Bin Dokuz Yüz Seksen Dört ${ }^{16}$ romanı gibi distopyalar içinde ele alınış1 heterotopyalar ile ütopyalar ve distopyalar arasındaki var olabilecek ilişkinin de irdelenmesi gerekliliğini doğurmaktadır. Foucault, "yok mekânlar" olarak ütopyaların karşısına, var (sonradan üretilmiş) ancak genel var olanın dışında mekânlar olarak heterotopyaları yerleştirirken ayna metaforuyla söz konusu karşıtlığ 1 ifadeye çalışır ve aynanın bir tarafındakinin düşlediği ve kendini yok olanda bulan bir varlık olarak ütopyalar ile heterotopyaların ilişkili tarihini tesciller. ${ }^{17}$ Kısacası ütopya; muntazam, sonsuz düzenin hâkim olduğu mükemmel şehir planları idealini modernite dairesinde yaşayan insana verirken şehirlerini birer ütopyaya dönüştürmek isteyenlerin tek tip insanlardan -'ben'- oluşan ütopya benzeri mekânlar kurma hayali onları öteki'ni dışlayan, öteleyen şehir planları da yapmaya sevk eder. Bauman, masum görünüşlü ideal şehir planlarının akıbetinin beklenenin aksine birbirinin kopyası olan mekânlar üretmek şeklinde uygulamaya geçirilmesinin modernitenin her bir noktayı en ince ayrıntısına kadar planlama itiyat ve kararlılığının sonucu olduğunu savunur. ${ }^{18}$ Foucault'nun işaret ettiklerinden hareketle, modernite ile bir yandan ütopya benzeri kentler inşa edilirken ve belirlenen sistem üzerine merkezdeki gösterenin göstergeleri konumunda bireyler üretmek gayesiyle toplum yönlendirilirken ve Bauman'ın dediği gibi en ince ayrıntısına kadar bu gidişat planlanırken bir taraftan da merkezdeki sistemin öteki'ler olarak belirlediği kişilerin ütopya olarak hayallenen kentlerden ütopyayı bozucu karakterleriyle uzaklaştırılması gerekliliğine inanışın bir sonucu olarak öteki, kapatma mekânları içinde sınırlandırılmaya başlanmış ve sonuç olarak da modernitenin ütopya ideali heterotopyaların doğuşunu hazırlamıştır denilebilir. Öteki'leri kapatmak üzere hazırlanan heterotopyaları ben'in kendisine yaşam alanları kurmak üzere kendinden dışsallaştırarak ödünçlemesiyle şehrin heterojen yapısı içselleştirilmiş bir kaotik tanzim planının toplumdaki tüm bireyler üzerine sosyolojik ve psikolojik etkilerini yadsınamayacak boyutta değiştirir. Asıl ilginç olan ütopyaların doğurduğu heterotopyaların distopyaların doğmasında hazırlayıcı bir basamak görevi de yüklenmiş olmalarıdır. Ütopya esasen ortaya çıkışı itibariyle ben'in hayalî bir öteki olarak ideal ben'i kapatma isteğinden doğar. Ben'in kapanma ihtiyacı ile ideal ben'ini hayalî düzlemde askıya alarak kapatma ihtiyacı arasında çok büyük bir fark vardır. Zaten askıya alınan ideal ben'in uzaklaştırılmasıyla geriye kalan ben'in öteki parçasının ideal'deki ben gibi hareket etmeyeceği ancak idealleştirdiğini istiyormuş gibi görüneceği ikili bir tutum izlemesi beklenir. Hayalde tutulan ideal ben'in

16 George Orwell, Bin Dokuz Yüz Seksen Dört, Çev. Nuran Akgören, 19. Bs., İst., Can Yay., 2008.

17 Michel Foucault, "Başka Mekânlara Dair", a.g.e., s. 295.

18 Zygmunt Bauman, Bireyselleşmiş Toplum, Çev. Yavuz Alogan, 2. Bs., İst., Ayrıntı Yay., 2011, ss. $84-86$. 
tümleyeni uzamsal ben'in heterotopyaya kapatılarak ideal ben'in kendisine ideal alanlar inşa sürecinin başlaması ideal ben'in zaferidir. Bu ideal ben, modernitenin temel çıkış noktalarına işaret eden ve genel insan yaklaşımından beslenen bir tasavvurî ideal ben'dir. İdeal olanın somutlaştırılması sırasında heterojenleşmenin sebebi baştaki idealleştirme kaydıdır. Bu bağlamda David Harvey; heterotopyaların, ütopyaların yükünü kolay kolay sırtından atamayacağı kaydını düşer. ${ }^{19}$ Gerçekten de sistemin ben'i kendi içinde parçalayan yapısı ideal ben'in tümleyeniyle özdeşleştirdiği öteki'ni kendi alanından uzaklaştırarak kendini somut mekânda deneyimlerken öteki'nin deneyimlemek zorunda kaldığı heterotopyanın bir distopya üreterek karşı harekete geçmesi ise kaçınılmaz hâle gelmektedir. Heterotopyalardan doğan distopyalar kadar ütopyaların da bulunuşu, panoptik sistemin sinoptik ve süper panoptik sistemlerin gelişimiyle eş zamanlı yaygınlaşması kaotik sürecin artık modernite dairesinden uzakta hipergerçeklik bağlamında postmodernite dairesinde süreceğinin alameti olarak okunmaya müsait görünmektedir.

Bir edebî tür olan romanın dört önemli unsurundan biri mekân olarak kabul edilmektedir. Romanlarda anlatılan mekânların soyut ya da somut mekânlar olup olmadığı, bir fon özelliği taşıyıp taşımadıkları, roman kişisinin iç dünyasının temsili aşamasında işlevsel bir rol üstlenip üstlenmedikleri önem arz etmekte ve romanda mekânın incelenmesi noktasında bu hususlara genellikle dikkat edilmektedir. ${ }^{20}$ Heterotopyalar sadece somut kapalı birer mekân değil, yukarıda belirtildiği üzere romanlardaki soyut birer mekân olan ütopyaların doğurduğu kabul edilen somut mekânlardır. Söz konusu somut mekân anlatımını takip eden ve onlarda/n/ doğan soyut distopya ve ütopya anlatımları sadece basit bir oyun değil modernite dairesindeki insanın neredeyse son dört yüz senelik mekân algısının değişimlerinin yakalanabileceği döngüsel ve girift bir yapının anlatımı olarak ifadelendirilebilecek önemli edebî eserlerdir. Edebî eserin gerçek mekânla, gerçek mekânın edebî eserle döngüsel bir şekilde, birbirini etkileyerek ortaya çıkardığı yapı; bir ucu gerçek mekânda bir ucu romanın ütopik dünyasındaki bir mobius şeridini andırmaktadır.

\section{Romanın İncelenmesi}

Buket Uzuner, 1992 senesinde yayımlanan romanı Balı İzlerinin Sesi ile Yunus Nadi Roman Ödülü’nü alır. Roman üzerine daha önce yapılan incelemelerde çoğunlukla romanın son kısmında yer alan ütopya adası üzerinde durulmuş ve roman genel olarak bu ütopya adası merkeze alınarak anlaşılmaya ve incelen-

19 David Harvey, Umut Mekânlarl, Çev. Zeynep Gambetti, 2. Bs., İst., Metis Yay., 2011, s. 227.

20 Nurullah Çetin, Roman Çözümleme Yöntemi, 4. Bs., Ank., Edebiyat Otağ1 Yay., 2006, ss. 136139. 
meye çalışılmıştır. ${ }^{21}$ Buket Uzuner'den evvel de heterotopyalar romanlarda pek çok yazar tarafından kurgulanmıştır. Ancak heterotopya bağlamında değerlendirilebilecek eserlerin tespiti, sıralanması ve incelenmesi çok ayrı bir çalışmanın konusu olduğundan ve makalenin sınırları dışına çıkılmak istenmediğinden bu makalede doğrudan romanın incelenmesine geçilmiştir. Çünkü bu makalenin amacı bir kavramın edebî eserlerde genel olarak nasıl incelendiğini ele almak ve incelemek olmayıp seçilen örnek bir eserde heterotopya kavramına uygun bir kapatma mekânını, anlatının getirdiği çeşitli açılım katmanlarıyla o eser dâhilinde yorumlamaktır.

\section{1. Ütopyadan Geliş}

Balık İzlerinin Sesi, romanın başkişisi Afîfe Pîri'nin milyonlarca genç arasından ülkesini temsilen seçilerek çıktığı uçak yolculuğunun anlatımıyla başlar. Afîfe, "Özel Burslu Seçilmiş Öğrenci” olarak bir kuzey ülkesine gidecek ve orada dünyanın her yerinden gelen kendisi gibi seçilmiş özel öğrencilerle birlikte bir sene boyunca kalacaktır. Bir hayale koşan Afîfe; hiç tanımadığı, uzak bir ülkedeki bir merkezde kendisi gibi özel ve seçilmiş insanlar arasında hayatında yaşadığ tüm sorunlardan, dışlanmalardan uzakta çok mutlu günler geçireceğine ve nihayet hak ettiği değeri göreceğine inanmaktadır. Afîfe'nin yolculuğu ütopya adalarına yapılan yolculuklara benzer. Ütopyaların anlatıldığı romanların ilk örneği kabul edilen Thomas More'un Utopia'sında Raphael Hytloday'ın ütopya adasını keşfi daha pek çok ütopyada olduğu gibi bir deniz yolculuğu vesilesiyledir. ${ }^{22}$ Romanın "Başlangıç" kısmı ütopya adalarına yapılan yolculuklara benzer bir yolculuğun

21 Buket Uzuner'in Balık İlerinin Sesi adlı romanı genellikle sadece romanın sonundaki ütopya adası bağlamında ele alınmaktadır. Bu çalışmaların en önemlileri arasında şunlar yer almaktadır: Betül Kaleli, "Buket Uzuner'in Hayatı ve Romanları Üzerine Bir İnceleme”, Elazığ, Frrat Üniversitesi Sosyal Bilimler Enstitüsü Sosyal Bilimler Enstitüsü Türk Dili ve Edebiyatı Anabilim Dalı, 2005 (yayımlanmamış yüksek lisans tezi). Yasemin Küçükcoşkun, "19802005 Dönemi Türk Edebiyatında Ütopik Romanlar ve Ütopyanın Kurgusu”, Isparta, Süleyman Demirel Üniversitesi Sosyal Bilimler Enstitüsü Türk Dili ve Edebiyatı Anabilim Dalı, 2006 (yayımlanmamış yüksek lisans tezi). Leyla Tuba Toptaş, "Buket Uzuner'in Hikâye ve Romanlarında Kişiler”, Sivas, Cumhuriyet Üniversitesi Sosyal Bilimler Enstitüsü Türk Dili ve Edebiyatı Anabilim Dalı Yeni Türk Edebiyatı Bilim Dalı, 2008 (yayımlanmamış yüksek lisans tezi). Talat Halman, "Balık İzlerinin Sesi ya da Ütopya'nın Sonu”, Varlık, S. 1026, Mart 1993, ss. 28-29. Cafer Gariper ve Yasemin Küçükcoşkun, "Buket Uzuner'in Kişilikler Oyunu ve Fantastik-Ütopik Dünyası: Balık İzlerinin Sesi Romanı”, Türkbilig, S. 14, 2007, ss. 69-96. Yasemin Mumcu Ay, "Ankara, Yalnızız ve Balık İzlerinin Sesi Romanlarında Ütopya”, Türk Dili ve Edebiyatı Araştırma Dergisi, C. XIV, S. 1, 2008, ss. 75-80. Firdevs Canbaz Yumuşak, "Ütopya, Karş1-Ütopya ve Türk Edebiyatında Ütopya Geleneği”, Bilig, Bahar 2012, S. 61, s. 61. Gürsel Aytaç, Çağdaş Türk Romanı Üzerine İncelemeler, 3. Bs., Ankara, Doğu-Batı Yay., 2012, ss. 406-407. Yıldız Ecevit, Kurmaca Bir Dünyadan, İst., İletişim Yay., 2013, s. 303.

22 Thomas More, Utopia, Çev. Sabahattin Eyüboğlu, Vedat Günyol, Mina Urgan, 18. Bs., İst., Türkiye İş Bankası Yay., 2014, ss. 5-6. 
anlatıldığı kısımdır. Afife'nin ütopya adalarına deniz yoluyla gidilebileceğine dair ilk dönem ütopyalarındaki genel söylemi tekrarlayarak yansıtan sözleri de bir ütopya adasına doğru yolculuğun gerçekleştirildiği kanaatini kuvvetlendirmektedir ("Aslında özüm denizdir. Çocukluğumdan beri denizlere sevdalıyım ben. Uzun deniz yolculuklarl yaptım, bir süredir de deniz ehliyetim var"23).

"Asıl Başlangıç" kısmındaysa seçilen başlığa uygun şekilde ben anlatıcı konumundaki Afîfe Pîri, seçilmiş seksen sekiz özel öğrenciyle kalacağı özel kampüsü bir ütopya adası gibi anlatmaya başlar. Çevresindeki tüm özel öğrencilerden ve onlarla birlikte yaşayacağ disiplinli hayattan umutlu Afîfe, günlerini mutluluk içinde geçirmektedir. Ütopyaların genel kusursuz karakterine uygun olarak tasvir edilen Fantolt konukevine dair tüm anlatılanlar bir masal atmosferini çağrıştırmaktadır. Anlatılanlara göre; sakin, huzurlu, herkesin "özel” olma noktasında birbirine benzediği, mutlu öğrencilerin yaşadığı bir mekân olarak Fantolt tasarlanmıştır. Akşit Göktürk'e göre ütopya adaları eserlerde; dünya dışında ve dünyanın karşıtı, dünyadan daha iyi ve daha mutlu yaşanabilecek, sınırlı ve d1şarıya kapalı olmaları sebebiyle toplumsal ütopyalar için uygun deney mekânları olarak sunulmakta; anlatılanın birey değil toplum oluşu edebî ada ütopyalarında bireyin öne çıkmasına engel olmakta; coğrafî keşiflerin tamamlanması ardından dünyada var olduğuna ve henüz bulunulamadığına inanılan düş adaları yerini "yok-ülke"lere bırakmakta; modern romanın insanın içine yönelmesiyle birlikte yazarlar ütopya adalarından kurgu kişilerin iç dünyalarını yansıtmak noktasında faydalanmaya başlamakta; düş adaları yirminci yüzyıl yazınında öne çıkan kaçış teminin kurguda somutlandığı mekânlar hâlini almakta; düş adalarda akan değil duran bir zamandan bahsedilmekte ve distopyalarda düşlere değil kâbuslara ev sahipliği yapmaktadırlar. ${ }^{24}$ Ütopya adalarının en önemli karakteristik özelliği dışa kapalılıktır. Fantolt, şehrin kırk bir kilometre uzağında (s. 11), dışa kapalı bir yerleşke olması açısından ütopya adalarıyla benzeşmekte; özel ve seçilmiş kişilerin bir arada yaşam deneyimlerinin sınanması açısından bir laboratuvarı andırmakta; dünyada oluşuyla ilk dönem ütopyalarını, ideal bir tasarım ve gerçekleştirilmesi zor bir hayal oluşuyla özellikle modernitenin gelişmeye başladığ 1 dönemin ütopya adalarını çağrıştırmakta; tüm dünya toplumlarında seçilmişlikleri ve özel oluşlarıyla öne çıkan kişilerin bir araya getirildiği bir sınırlı alan olarak tam bir ütopya ideali özelliği taşımakta; zamanın belirsizliği ve durağanlığ da söz konusu ütopya tasvirini desteklemektedir. Özel ve seçilmiş öğrencilerin Birleşmiş Milletler tarafindan kurulan bu merkezde gerçekleştirdikleri tek bilimsel faaliyet seçtikleri çeşitli konularda seminerler vermektir. Bu seminerler

23 Buket Uzuner, Balık İzlerinin Sesi, 22. Bs., İst., Everest Yay., 2012, s. 4. Bundan sonra metinden yapılan doğrudan ya da dolaylı alıntılar metin içinde sayfa numarası ile gösterilecektir.

24 Akşit Göktürk, Ada: İngiliz Yazınında Ada Kavramı, 3. Bs., İst., YKY, 1997, ss. 9-12, 17-18, $31,115,117,130,172,152-160$. 
haricinde isterlerse yemeklerini hazırlayabilen öğrenciler, sadece haftada bir gün çarşaf ve nevresimlerini değiştirmekten sorumludurlar.

Ütopyanın gerçekleştiği mekân olarak tanitılan Fantolt'un bir akıl hastalıklar1 hastanesi olduğunun anlaşılmasıyla romanda bir ütopya olarak anlatılan merkezin gerçek yüzü açığa çıkar. Ütopyalar tarih boyunca insanın kendine (kendi idealindeki ideal ben'ine, olduğunu varsaydığı ben'e) benzer kişilerle birlikte sorunsuzca, sonsuz yaşayabileceği birer ideal yaşam alanı olarak tasarlanmıştır. Ütopyalardan etkilenen şehir planlamacıları da ütopyalardaki tek tip insanın yaşayacağı 'mükemmel' alanlar tasarlayarak ütopyaları gerçeğe taşımaya çalışmışlardır. Ütopyaların gerçeğe taşınma ve şehirleri birer ütopya adasına dönüştürme çabası ise yukarıda da bahsedildiği gibi heterotopyaların doğuşunu hazırlamıştır. Afîfe Pîri'nin algısına bağlı olarak bir akıl hastanesi bir ütopya yerleşkesi olarak ilk başta tanıtılırken okur aslında ütopyalara dair bir eleştirel okumayla karş1laştığının farkına çoğunlukla varamamakta, bir tür mutluluk oyunu oynandığını zannedebilmektedir. Okuyucuya tanıtılan aslında bir ütopya adas1 ya da ütopya yerleşkesi değil; ütopya fikrinden doğan bir tasarımın sonucu ortaya çıkan bir heterotopyadır. Dr. Frankenstein'ın ölümü yenebilme düşüyle çıktığı yolda kendi eliyle yaptığg ucubenin düşlerindekinden uzak hâliyle karşılaştığ 1 anda yaşadığı hayal kırıklığı, ütopyayla yola çııı heterotopyaları bulan modern insanın dramına çok yakındır. Özenli, çift yönlü anlatımı yazarın heterotopyaların ütopyalardan doğuşuna dikkat çekme yöntemi olarak romanda kullandığı rahatlıkla söylenebileceği gibi idealin gerçeğe taşınması noktasındaki büyük değişim ortak kaynaktan beslenen ütopya ve heterotopya içindeki sistemin benzerliği sebebiyle kolay fark edilememektedir. Zaten romanda ayrıntılı bir okuma yapıldığında asıl işaret edilmek istenenin de bu benzerlik olduğu anlaşılmaktadır.

\subsection{Heterotopya}

Afîfe Pîri tarafından bir ütopya yerleşkesi gibi tanıtılan şehirden uzak, yoldan geçenlerin fark edemeyeceği şekilde ormanın içine gizlenmiş olan Fantolt'un sadece bir kuzey ülkesinde yer aldığından romanda bahsedilmekte ancak hangi ülkede ya da şehirde bulunduğu açıkça belirtilmemektedir. Romanda geçen Norveççe cümleler, mimaride kullanılan on yedinci yüzyıla ait rokoko üslubundan bahsedilmesi, bulunulan şehirde beyaz ahşap evlerin ağırlıkta oluşu, fiyortlar, kuzey ışıkları, romanda satıldığından bahsedilen Klassekampen gazetesi bu ülkenin Norveç olduğunu göstermektedir. ${ }^{25}$ Tek diş mekân olarak ziyaret edilen ve bir müze oluşuyla yine bir heterotopya olma özelliği taşıyan Edvard Grieg Museum, Norveç'deki Bergen kentinde bulunmaktadır. Buket Uzuner, burslu bir öğrenci

25 Cafer Gariper ve Yasemin Küçükcoşkun da romanda anlatılan mekânın Norveç (Bergen) olabileceğini düşündüklerini mübahis makalenin bir dipnotunda belirtmektedirler. Cafer Gariper ve Yasemin Küçükcoşkun, a.g.m., s. 71. 
olarak bulunduğu Bergen'den Gezi Notları içinde de bahseder. Özellikle Siyah Saçlı Kadının Gezi Notları'nda "Kara Kafa"26, "Kendi Başımayım Ben; Başıma Buyruk!"27 ve "Tanıdığım İlk Dünya-İnsanı: Carol”28 bölümleri başta olmak üzere kitap boyunca Bergen'i ve orada yaşadıklarını anlatır. Kitabını "Tuula, Karin, Carol, Kate, Carmen, Karen, Helena, Satu ve tanımadığı[.] öbür cesur ve akıllı kadınlara" 29 ithaf eden Uzuner'in bu isimlerden bazılarını Bergen Üniversitesi'nden tanıdığı anlaşılmaktadır. Aynı isimlerden yazar, Balık İzlerinin Sesi romanındaki bazı kurgu kişilerin adlandırılmasında da yararlanmaktadır. Uzuner'in günlük hayatta karşılaştığı isimlerden roman dünyasında istifadesini göstermesi açısından bu bilgi önem arz etmektedir. ${ }^{30}$ Kurguda yaşayan mekânlar olarak ütopyalarla gerçek hayattaki mekânlar olarak heterotopyalar arasındaki gerçek-kurgu bağlamındaki ilişki böylece romanda farklı bir açıdan da isimler üzerinden desteklenmiş olmaktadır. Romanın modernitenin, ütopyanın ve heterotopyanın doğduğu ve geliştiği Avrupa'da geçiyor oluşu da söz konusu kavramalara dair doğru okumalar yapılmasının önünü açan yazarın yerinde bir tercihidir.

Birleşmiş Milletlere ait bir merkez olarak tanıtılan Fantolt, üç binadan oluşmaktadır. Ortada bulunan J blokta seçilmiş özel öğrenciler kalmakta olup binanın on katlı olduğu ifade edilmektedir. Sağdaki beş katlı A blokta Birleşmiş Milletler görevlilerinin odaları bulunmakta soldaki yedi katlı $\mathrm{M}$ blok ise eğitim, spor, sağlık, dinlenme, eğlence, çamaşır yıkama ve kurutma için kullanılmakta, bu blokta bir de self-servis lokanta yer almaktadir (s. 11). Bir ak1l hastanesi olan heterotopyanın dış dünyadaki çeşitli faaliyetlerin gerçekleştirildiği mekânları taklîden kendi içinde kopyalayarak sistemine dâhil ettiği görülmektedir. Lokanta ve toplantı salonu dışındaysa bu birimlerin herhangi birinin kullanıldığına dair roman boyunca herhangi bir bilgi verilmemektedir. Öğrencilerin haftada bir çarşaf ve havlularını biriktirdikleri kirli çamaşır torbalarını teslim ettikleri bodrum katında yer alan, binadaki tüm ahşap kapıların aksine kırmızı çelik kapılı çamaşırhanenin üstündeki

26 Buket Uzuner, Bir Siyah Saçlı Kadının Gezi Notları, İst., Everest Yay., 2010, ss. 1-8.

27 A.e., ss. 9-20.

28 A.e., ss. 21-27.

29 A.e., s. V.

30 Olayların geçtiği belirtilen Fantolt merkezi, şehirden uzak bir orman içinde yer alması ve isim benzerliği açısından Bergen'deki "Fantoft" adlı 1150'lerde yapılmış bir ahşap kiliseyi çağrıştırmaktadır. Ayrıntılı bilgi için bkz.: http://www.bergen-guide.com/47.htm (20.01.2015), http://www.fantoftstavkirke.com (20.01.2015).

İsim seçimi konusunda Fantoft'un bir kapanma mekânı iken bir kapatma mekânı olan Fantolt'a isim babalığı yapması, insanın mekân pratiklerinin değişimine dikkat çekmesi açısından önemlidir. Makalede roman otobiyografik unsurlar açısından değerlendirilmediğinden yer verilmemekle birlikte, Buket Uzuner'in bir öğrenci olarak gittiği Norveç'in Bergen kentindeki üniversitede geçen çalışma döneminde bir heterotopya olan üniversite kampüsüne dair değerlendirmeleriyle romandaki ütopya ve heterotopya anlatımları arasındaki yakın ilişkiyi de tespit etmek gerekir. 
"True Laundry" (s. 10) (gerçek çamaşırhane) levhası özellikle heterotopyadaki sahteliği gözler önüne sermekte ve heterotopyanın aldatıcı karakterini imlemekte, bir taraftan da çamaşırhane tabelasının yer aldığı ancak gerçek çamaşırhane olmayan farklı bir mekânın daha hastanede bulunduğuna işaret etmektedir.

Seçilmiş özel öğrencilerin kaldığı binada panoptik sistem sürekli işletilmektedir. Sürekli bir düzenin hâkim olduğu binanın öğrencilerin kaldığı J bloğunda, Bentham'ın tasvirindekine çok benzer şekilde, "her katta dokuz oda ve bir büyük mutfak uslu uslu yan yana dizilmişlerdir"(s. 11). Dikkat edilecek olursa yazarın kullandığ “ "uslu uslu” ve "yan yana dizil[mek]" ifadelerinin Bentham'ın panoptik sistemin merkezdeki kuleden rahatlıkla suçluları, akıl hastalarını ya da öğrencileri gözetleyebilmek için yan yana dizdiği ve içlerinde gözetlenenlerin usluca kalmalarını beklediği hücrelerden oluşan yapısını tarifine çok benzediği görülecektir. Afîfe'nin başlangıçta anlam veremediği ve her odada tek bir kişinin kalmasının basit bir tercih olduğunu sandığı hücre tipi odalardan oluşan bina tasarımı Bentham'ın sistemiyle uyum içindedir (s.10). Binanın koridorlarında "keskin bir aydınlatma" bulunmakta olup gece gündüz aynı aydınlatma sistemi kullanılmakta ve bu sayede "koridorda hiçbir noktaya gizlenme şansı bırak [ılmamaktadır]" (s.11). Aynı panoptik sistemde olduğu gibi sürekli bir gözetleme işlemi Fantolt dâhilinde gerçekleştirilmekte koridorlardakine benzer bir gözetleme sistemi öğrencilerin odalarında da sürdürülmekte, her odada birer dinleme aygıtı bulunmakta ve öğrenciler sürekli dinlenmektedirler (s. 75). Öğrenciler dinlendiklerinin, gözetlendiklerinin farkına varsalar da dinleyeni, gözetleyeni görememekte yine de bu bilgi dâhilinde her daim gözetim altında tutuldukları inancıyla hareket etmektedirler. Merkezdeki sürekli gözetimin nişanesi bu dinleme aygitlarıysa sürekli takibin ve kontrolün nişanesi de kimlik kartlarıdır. Binada bulunan tüm öğrenciler üzerinde isimlerinin, geldikleri ülkenin sembolik harflerinin ve oda numaralarını da içinde barındıran kimlik numaralarının bulunduğu birer kimlik kartı taşımaktadırlar (s. 12).

Binanın ilk dört katından genel olarak Afîfe hiç bahsetmez. Öğrencilerin on katı binanın beş ve üzerindeki katlarında kaldıkları anlaşılmaktadır. Beşinci katta Carmen de Cervantes, altıncı katta yan yana odalarda Afîfe Pîri (682 numaralı oda) ve Romain Kacew (688 numaralı oda), yedinci katta Tuula, sekizinci katta 810 numaralı odada Brooks, dokuzuncu katta 913 numaralı odada Cyrano kalmaktadır. Bodrum katıyla birlikte on bir katlı olan binanın tam merkezine romanın iki önemli kişisi Afîfe Pîri ve Romain Kacew yerleşmişlerdir ve onların odalarının numaralanma sistemi diğer katlardan farklı olduğu gibi aynı katta yan yana odalarda kaldıklarından bahsedilen iki kişi olmaları sebebiyle de diğer kişilerden ayrıldıkları ve romanda öne çıktıkları görülür. 682 ve 688 numaralı odaların, her katında dokuz oda ve bir mutfağın yan yana yerleştirildiği bir sistemde art arda gelebilmeleri için dairesel ya da döngüsel kapalı bir yapıdan bahsedil- 
mesi gerekir. Düz bir koridorda aynı büyüklükte, birbirinin eşi odaların yan yana gelmesi mümkün olsa da ilk ve son odalar yan yana gelemeyecektir dolayısıyla sistemin dairesel, döngüsel kapalı bir sistem olması şarttır. 810 numaralı bir odanın bulunması, oda numaralarının sıfir ile başladığını göstermektedir. Her katta tıpkı Jeremy Bentham'ın tarif ettiği gibi panoptik sistemin uygulandığı bir oda diziliminin söz konusu olduğu sonucuna romanda işaret edilenlerden hareketle varmak mümkün olabilmektedir.

Heterotopyanın sırrı "seçilmişlik" kavramında gizlidir. Herhangi bir kişinin diğerini seçiyor oluşu esasen seçilenin ne için seçildiğini anlamsızlaştırmaktadır (özel burslu öğrenci ya da akıl hastası). Seçen-seçilen arasındaki ben-öteki ilişkisinin temel dinamiklerinin belirleyicisi ben'dir. Roman kişisi Afîfe Pîri'nin romanda önce bir ütopya gibi tanıttığı ancak bir heterotopya olduğu anlaşılan Fantolt, "seçilmişlik" kavramı etrafinda oluşturulmuş, süslenmiş bir merkezdir. Öteki seçilerek ben tarafindan kapatılmak formülüyle özetlenebilecek heterotopyanın anlatımı boyunca romanda özellikle "normal" ve "seçilmiş" kavramları ben ve öteki'ne gönderme yapacak şekilde diyalektik zıtlık bağlamında anlatılmakta, bireyin merkeze yerleştirildiği sistemde normal olanın seçtiği ve öteki olarak nitelendirdiğini kendini de tanımlamak üzere kullandığı görülmektedir. Fantolt içinde normalleri/ben'i temsil eden kişilerin bulunuşu heterotopyanın, yukarıda da işaret edildiği gibi, öteki'nin kapatıldığı mekâna ben'in de dâhil edildiğini göstermesi açısından kıymetlidir. Heterotopyalar, ortaya çıkışları ve yapıları gereği sürekli çatışmayı gerekli kılan, itaati hedeflerken isyanı körükleyen kaotik merkezlerdir. Öteki'nin ben'e dönüştürülmesi heterotopyalarda Foucault'nun tespitiyle "normalleştirme" ${ }^{11}$ ideali doğrultusunda gerçekleştirilmek istenmektedir. Buket Uzuner, Balık İzlerinin Sesi boyunca aynı kavramı kullanır, ötekiler "normalleştirme"ye boyun eğmek istemeyen, normalleşmekten ve normalleştirilmekten korkan, kaçan, kendilerinin "normal olmayan" olarak tanımlanmasından hoşlanmayan ancak "seçilmişlik" kavramının ben tarafından seçilmeyi de ifade ettiğinin farkına varmayarak cazibesine kapılan kişiler olarak tanıtılırlar.

Buket Uzuner, ben-öteki diyalektiği bağlamında ben'i ve öteki'ni, normali ve seçilmişi, onların özelliklerini; ben'in kullandığı sistemin dışına çıkmadan, onun düşünce pratikleri ve sistem oluşturma aygitlarıyla belirlemeye, sınırlarını tespite dolayısıyla sınırlandırmaya çalışır. Heterotopyayı üreten düşüncenin dışına çıkamaz, sadece ben ile öteki'nin yerlerini değiştirme gayreti içindedir. Öteki'nin ben olarak konumlandırıldığı bir sistem ile ben'in öteki olarak konumlandırıldığ sistem arasındaki tek fark ben yerine öteki'nin ve kurallarının geçmesidir. Öteki/ seçilmiş de roman boyunca aynı ben gibi davranır, ben'i yargılar, mahkûm eder ve ben'in öteki'nden kaçarak hayallerinde sığındığı ütopyalarına benzer bir ütop-

31 Michel Foucault, "Başka Mekânlara Dair”, a.g.e., s. 297. 
ya düşlemekten uzak kalmaz. Romanın sonundaki ütopya adası ben'i öteki'siz bırakma tehdidine işaret etmekte, ben öteki'ne yaşam hakkı tanımadığı takdirde bir öteki'nden yoksun bırakılmakla, diyalektik açıdan boşa düşürülerek kurduğu sistemin yıkılmasıyla tehdit edilmektedir. Öteki'nin isyanı romanda, öteki olarak tanımlanmaya değil, öteki olarak sahip olmak istediği hakları elde edemeyişine yöneliktir. Ben tarafından tanınacak haklara, müsamahaya ihtiyacı vardır ancak bu hakları bir öteki olarak istedikçe zaten kendisi de ben'in kendisine yönelik öteki tanımlamasını içselleştirdiğini ve ben'in sistemdeki merkezi konumunu tasdiklediğini fark etmemektedir. Dolayısıyla ya ben'e dönüşmeyi (ben dönüşümü beklediğini söylese de esasen dönüşümü istemez) ya da öteki olarak kalmayı kabul edecektir.

Seçilmiş̧ler, roman içinde kendilerini ve normalleri normallerin diline özgü kavram ve nitelemeleri ödünçleyerek tanımlarlar. Öteki'nin/seçilmişlerin açısından romanda 'normal'ler; basit ve zordan uzak bir yaşamı tercih ederler; hayatlarını ayıp kavramı etrafına inşa ederler; öteki' lerin hayatı için büyük bir tehlike oluştururlar; tanımlamalar yapmaktan ve genellemelerden hoşlanıp insanları da tanımlamaya, etiketlemeye çalışırlar; kadın ve çocukları çoğunlukla insanın gelişmemiş bir türü gibi görürler; hayalleri kısırdır, sınırlıdır (s. 4, 18, 19, 23, 47, 81); "her eylemin içinde ille bir güç ya da cinsellik unsuru olabileceği saplantısıyla dünyaların iyice daraltırlar" (s. 100); "düzen"i, "disiplin"i, "aktöre"yi savunurlar; gösterişi severler, saygınlık kazanmanın peşindedirler; toplumun çoğunluğunu oluştururlar; duygusal açıdan zayıf görünmekten korkarlar; ötekilere şiddet ve bask1 uygularlar, onları korkuturlar (s. 113, 118, 113, 153, 22); genel olarak işlerini, hayatı ve kendilerini sevmezler. Seçilmişler roman boyunca normalleri eleştirirken yaptıkları eleştirilerin seçilmişleri normallere daha çok bağladığının ve kendilerini eleştirenin konumuna bizzat yerleştirdiklerinin ayırdında değillerdir. Normallerin eleştirisi genel olarak tüm modernite dairesi pratiklerini kapsayacak şekilde geliştirilen bir iç isyan şeklinde algilanacak boyutta olup modernite eleştirisi bağlamında Batı'da felsefeciler ve sosyologlar tarafından son yüz elli, iki yüz senedir geliştirilen düşünce akımlarıyla çoğu noktada örtüşmekte, aynı düşünceleri tekrarlamakta, yeni bir şeyler söylemekten uzak olup bu çerçevede üretilen görüşlerin romanda kurgusal açıdan somutlaştırılmış roman kişilerine topluca öteki adına söyletilmesi sadece bir toparlama çabasından ibaret kalmaktadır. Seçilmişlerin normallere dair yaptıkları tanımların ardından kendilerini de aynı şekilde -tanımlamalara karşı olduklarını belirtseler de- normaller üzerinden tanımladıkları bu noktada da normal'ler olarak adlandırdıkları ben'in pratiklerini ve tanımlama sistemini tekrarladıkları görülür. Romanda seçilmişleri normallerden farklılaştıran, onların zıt kutbuna yerleştiren en önemli özellikler olarak şunlar sayılmaktadır: Seçilmişler komşuluğun sun'î bir ilişki olduğuna inanırlar (s. 12); "bürokrasi, örgütlenme ve yönetsel kaygılar[a]" uzaktırlar ve 
normallerin aldığ beğenilmek kaygıları yoktur; seçilmişler düşünceleri ve hayalleri noktasında birbirlerine benzerler; normallerin dünyasında yaşayabilmek için "MIŞ GİBİ" oyununu öğrenirler ve oynarlar; normallerin aksine şaşırtmaktan, beklenmeyenden, bilinmeyenden hoşlanırlar; sevginin fazlasından yakınırlar, dinlemekten hoşlanmazlar, kendilerini severler ve suçluluk duymazlar; başkalarının özel hayatıyla ilgilenmekten hazzetmezler; "savunma ve gizlenme güdüleri" gelişmemiştir (s. $24,26,27,33,35,37,105,40,110$ ). Dikkat edilecek olursa insanlardan ayrı bir tür gibi (güdüleriyle) bahsedilen seçilmişlerin genelin üstünde bir ast-üst ilişkisi içinde konumlandırılmaya çalış1ldığı görülür. Üstünlüklerini özel bir mutasyona bağlayan seçilmişler, hiçbir homo sapiens'in bu mutasyona sahip olmadığından kendileri kadar bireysel olamadığına çünkü kendilerinin bireysellik genlerinin gelişmiş olduğuna inanırlar (s. 125). Evrimsel bir temelde ötekinin gelişmişliği böylece vurgulanmak istenirken geri dönüşümsüz ve geliştirici, aynı zamanda türden ayırıcı özellikler yükleyici vasfiyla bahsi geçen mutasyona dayandırılan öteki'nin farklılığı fikri böylece öteki'ler tarafından genetik zeminde kabullenilmiş olur ki yukarıda sayılan ötekilerin hiçbir özelliğinin kendilerinin bilinçli tercihine dayanmadığını vurgular. Söz konusu kabul normal'in seçilmişi, öteki olarak konumlandırmasının haklı gerekçelerinin öteki'nin ağzından beyanı niteliğini taşımaktadır. Öteki'nin ayrı bir tür olarak kabulü (öteki tarafından da içselleştirilmiş bir bilgi olarak) Batı'nın modernite bağlamında yaptığı tür tasniflerini çağırır. Mübahis anlayışın neticesinde on dokuzuncu yüzyıl Avrupa'sında Miss Julia Pastrana (hirsutizm hastası), Krao, Aslan Adam Lionel, Benekli Negro (vitiligo ya da pigment eksikliği hastası) ve daha niceleri sadece birer seyirlik nesne hâline getirilebilmiş ayrı bir türün numuneleri olarak sergilenebilmişlerdir. ${ }^{32}$ Afrikalı, farklı ten rengine sahip, Doğu, kadın tür tasnif denemeleriyle öteki sayılmak üzere asıl tür'den (ben'den, normal'den, insandan) uzak öteki türler olarak sınıflandırılarak toplumdan ayrılanlardan sadece birkaçıdır. Öteki'ni insan-dış1 sayılan türe ait addetme insanın öteki'ne her türlü müdahalesini haklı gösterme gayretinin ürünüdür. Romanda normallerin çoğalma konusunda seçilmişlerin çok ilerisinde oldukları için seçilmişlerin toplumda azınlık hâline geldiklerinin belirtilmesi söz konusu mutasyona bağlı olarak ortaya çıktığı varsayılan genin aslında oluşturduğu türün ölümüne de sebep olduğu savını içinde barındırır ki zaten bu varsayım normal'in müdahalesi olmadan da seçilmiş'in sonunun yaklaşmakta olduğunu gösterir. Bir taraftan da 'seçilmişlik' kavramının ben'e değil gen'e bağlanması ben'i temize çıkarmakta ve her türlü edimini türler arası bir savaşta haklılık payesiyle onurlandırmaktadır. Güçlünün kazanacağı savının genel kabu-

32 Sibel Yardımcı, “Canavar: Kültüralizm Ne Zamandı?”, Çağdaş Sanat ve Kültüralizm: Kimlik ve Estetik, Der. Ali Artun, Çev. Tuncay Birkan, Nursu Örge ve Elçin Gen, İst., İletişim Yay., 2013, ss. 134-136, 138. 
lü zaten söz konusu mutasyona dayalı anlayışın devamında ileri sürülecek yegâne fikir olarak doğmuş ve güçlüyü (güçlü olduğu iddiasıyla ortaya çıkanı) haklı mertebesine getirmiştir. Bu görüşün neşv ü nema bulması sonucu ortaya konulan fikirlerin sistemleştirilerek somutlanması heterotopya adı verilen mekânların modernite dairesinde doğuşuna zemin hazırlamıştır.

Ütopyalarda kişiler hep birbirinin aynısı, ideal ben'in kopyaları şeklinde üretilirler. Kişilik özellikleri ön plana çıkarılmaz. Akşit Göktürk ütopyalarda anlatılan kişilerin kişilik özelliklerine yer verilmemesinin sebebini yazarın bireyi değil toplumu anlatma gayesine bağlar. ${ }^{33}$ Psikolojik açıdan yaklaşıldığındaysa ben'in özgür evreni fikrinden doğan ütopya; öteki'lerle paylaşılamayacak kadar müstesna, öteki'lerden bahsedilmeye gerek görülemeyecek kadar şahsî ve ideal ben'in yüceliği üzerinden ben'in tüm psikolojik tatminini sağlamaya elverişli birer soyut mekân olarak ben'in rüyalarını süslerken ideal ben'in mimetik çoğaltımıyla oluşan bir topluma işaret etmekte ve esasen ben'in merkezine yerleştiği usçu sistemin hazcı ayağında bir toplum numarası yapan ben'ler gösterisinden ibaret kalmakta dolayısıyla toplumu değil ben'i hedeflemektedir. Sonuçta da ütopya her zaman algısal ben suretleriyle sorunsuz bir sistem düşü olmanın ötesine geçememektedir. Distopya, ideal ben'in suretleriyle dolu bir fantastik dünyadaki hegemonyasına karşı çıkan asi ben'iyle çatışmasının anlatımıdır. Sun'î, mükemmel görünümü dağıtan, hayale sizarak onu kâbusa dönüştüren bu asi ben, distopyalarda çoğunlukla sadece isyan aşamasındadır. Distopyaların kaotik yapısı yeni bir ütopyada asi ben'in idealleşme/kendini yeni ideal olarak merkeze yerleştirme sürecinde durgunlaşırken distopya ortak bir paydada ütopyayla insanın kendi kopyalarını üretmesi noktasında eşitlenmektedir. İdeal ben'in ütopyalardaki mimetik üretim tertibini pratikte öteki'ne yansıtarak çoğunluğu tekil algılama girişiminin bir sonucu olarak ayrı bir tür şeklinde öteki'ni kabulü genel bir çerçevede bireyleri teker teker değil topyekûn değerlendirme girişiminin adı olur. İdeal ben'in öteki'nin kendi hayallerine sızamayacağ1, dünyaya ait bir mekânda gönüllü ya da gönülsüz prangalama teşebbüsünün ismi heterotopyalar olur. Ütopyadan doğarken ütopyanın dağılmasına karşı da bir tedbir olarak kullanılan mekânlar hâlini alan heterotopyalar, eş örneklerden mürekkep bir topluluğun kapatılma mekânı olarak ütopyalara kapatılan ideal ben suretleri topluluğunun hayallerden dünyaya negatif yansımasını andıran öteki'ler genel sınıfının kendi içinde benzerliği noktasında ütopyalarla benzeşirler.

Heterotopyalar içeriden anlatılırken heterotopyaya kapatılan ötekilerin bir tür olarak genel şekilde anlatımı değil, farklı kişilik özellikleri sergileyen bireylerin ayrı ayrı anlatılması beklenir. Genel isimleriyle hasta, deli, suçlu, yaşlı, ölü, öğrenci vs. şeklinde kapatılacak öteki olarak genellemeye dayanan anlatım ise 
ben'in heterotopyaya kapattıklarını genel bir tür olarak nitelendirme gayretkeşliğinin doğurduğu dilin, üslubun özellikleridir. Heterotopyayı dışarıdan anlatan, genelleme yapan dili; içeriden anlatan ise genellemeden uzak, bireysel bir dili kullanır. Genel bir tespit yapmak gerekirse heterotopyalar dışarıdan anlatılırken ütopyaların dili, içeriden anlatılırken ise asi ben'in henüz ideal ben'e isyan aşamasında olduğu distopyaların dili kullanılmaktadır. Buket Uzuner romanda bir taraftan içeriden anlatımı seçerken bir taraftan da sürekli bireysel olandan kolektife doğru ilerleyen bir tutumla ütopyaların dilini ödünçler. Başlangıçtaki ütopyanın anlatımında sadece Afîfe'nin anlatımı vardır ve öteki ben dilini kullanmaktadır, heterotopya içinde bireysel tanıtımlar ve kişilerin söz alması da vâkidir ancak ben anlatıcı hiçbir zaman anlatının dilini bırakmaz, hâkim konumunu içeriden anlatımda dahi sürdürür. Hatta heterotopyadan doğan, romanın sonunda sanrısal ütopyanın anlatım aşamasında bir ara yazar dayanamaz ve Afîfe'nin elinden hâkim ben sıfatıyla anlatıcılığı da alır (s. 190). Romanın sonunu ideal ben sifatıyla yazar tamamlar. Böylece ütopyanın dili sonunda ütopya dilinin asıl sahibi yazara, ideal ben'e geri döner.

Balık İzlerinin Sesi'nde bir akıl hastanesi olduğu anlaşılan Fantolt'taki kişiler özellikle bir öteki olanın, Afîfe'nin gözünden tanıtılırlar. Romanın başkişisi olan Afîfe ise kendisini tanıtır ya da Afîfe'nin başkalarıyla ilişkisi esnasında bulunduğu yargılar dolayısıyla okuyucu bazı çıkarımlarda bulunmak suretiyle onun kişiliği hakkında bilgi sahibi olur. Afîfe Pîri, Afîfe Jale ile Pîri Reis'in kuşak farkıyla torunudur. Hastanedeki en genç hastadır ve kendi adını heterotopyada ben'e göre, ben'in baskısıyla değiştirmek zorunda kalmayan tek hastadır. Annesinin şefkatini ve sevgisini kendi üzerinde bir baskı aracı olarak kullanmasından ve dostluklarında aldığ 1 yaralardan mustariptir. Normal'lerin konuşmalarına dayanamayıp bayılabilen, hassas bir tabiata sahiptir, kendine ait ütopik dünyasında yaşamanın ve normal'lerden kaçmanın yolunu arar. Romain Kacew'in hem en yakın arkadaşı hem de sırdaşı, yönlendiricisi, akıl hocası ve âşık olduğu adamdır. Romain Kacew, Romain Gary hatta Emile Ajar müstear adını da kullanan bir yazar olduğu bilinmektedir. Afîfe Pîri'nin kurgu içindeki heterotopyada anlattığ1 Romain Gary'nin gerçek Romain Gary'nin kimliğini benimsemiş bir şizofren mi yoksa heterotopyanın farklı zaman ve mekâna ait unsurları olduğu gibi kişileri de bir araya bağlamından kopararak kolajlayan yapısına göndermeyle heterotopyaya ütopyalar kurgulayan yazar kimliğiyle eklenmiş, eklektik yapıyı güçlendirici bir roman kişisi mi yoksa Afîfe'nin düşlerinde, varsanılarında yaşattığı ve sevdiği bir yazar mı olduğu anlaşılamaz. Anlatının tüm bu yorumlara açık yapısı bizatihi heterotopyanın temel dinamikleriyle örtüşür. Gözetlenenin gözetleyen dışındaki dünyasına işaret eder. Kapatmaya karşı geliştirilen bir tür ruhî kapanma eğiliminin keşfiyle kapatılan, kendi iç dünyasında sanrılarıyla, varsanılarıyla baş başa kalarak dengeyi sağlamayı dener. Çünkü heterotopya iç içe geçmiş kapatma-ka- 
panma pratikleri halkalarından oluşur. Düştükçe derinleşen bir kuyuyu, içinde kaybolundukça gücü artan bir kara deliği, başta mekânı ve zamanı içine doğru çeken, yutan güçlü bir burgacı andıran heterotopya ben'i de yutacak şekilde sanrilar, varsanılar hazırlar.

Romain Gary, annesinin hatırasından ve ona olan hastalıklı sevgisinden bir türlü kurtulamayan bir kişilik olarak anlatılırken hastanede kalan diğer kişiler de farklı psikolojik hastalıklarıyla tanıtılırlar. Tuula olarak bilinen ve Jeanne d'Arc'in torunu olduğunu söyleyen Jeanne, hermafrodit bir tablo gibi çizilir. Sağdan kadın, soldan erkek gibi görünen gözleri farklı anlamları barındıran, firijit bir kadindir (s. 14, 106). Carmen de Cervantes, Miguel de Cervantes'in torunudur ve toplumsal tabuları yıkma peşindedir. Aurore Sand, dengesiz ve nekrofilik bir kişilik yapısına sahiptir (s. 29). Brooks Nin, bir teşhircidir (s. 52). Parveen Nehru ise Hintli bir katildir ancak hayatındaki bazı dönemlerin kayıp olması romanda belirtilmese de Nehru'nun dissosiyatif kişilik bozukluğu hastası olabileceğini düşündürür. Müzisyen Edward Grieg'in torunu olarak tanıtılan Anders Grieg, aynı zamanda Afîfe'nin Romain ile aynı anda âşık olduğu adamdır. Edmond, Cyrano adıyla heterotopyadaki hastalar arasında tanınır ve sürekli şiirler okur. Afîfe hastanede kaldığı süre zarfinda isminden bahsedildiğini duysa da Mösyö G.G. yani Galilei Galileo ile bir türlü tanışamaz. Bir Türk Yahudisi olarak romanda tanıtılan ve Chagall'in torunu olduğunu söyleyen Roni, dedesi gibi ressamdır. Ayrıca Don Quihote'nin akrabası Donna Quijota da hastanede kalanlar arasındadır. Hastaların genel eğilimi ötekiliğin seçilmişlik olarak kabulü yönündedir. Hastalar kendilerine isnat edilen hastalıkları kabul etmezler aksine yaşadıklarının normal'lerin anlayamayacağı özel hâller olduğunu düşünürler ve bu noktada birleşirler. Hastanede normal olarak tanıtılan üç kişi bulunur. İlki Doktor Gunnar'dır. Diğeri Afîfe'nin başlangıçta temiz çamaşır memuresi zannettiği hemşire Vigdis diğeri ise ona ikizi kadar benzeyen hemşire Astrid'dir. Bahsi geçen ikizlik ben'in kopyalanarak kendisini çoğaltma eğilimine de bizatihi bir gönderme olarak kabul edilebilmeye müsaittir. Ayrıca hastaların odasını haftada bir temizledikleri belirtilen öğrencilerin de merkezde bulunduğu belirtilse de Afîfe bu öğrencilerle karşılaştığından roman boyunca hiç bahsetmez.

Hastanede sağaltım aşamasında hastaların bir araya toplanarak hastalıklarının sebeplerini irdeledikleri toplu seanslar gerçekleştirildiği anlaşılmaktadır. Afîfe'nin zaman zaman duyduğu yanık kokusu (s. 30) bunun akabinde beyninde bir yanma, karıncalanma hissetmesi (s. 51), bir tür elektroşok işleminin hastaya uygulanmakta olduğunu akla getirmektedir. Bunun yanında hastalar düzenli olarak oral yoldan pembe haplarla tedavi edilmekte (s. 43), hastalığın seyri ağırlaştığındaysa serum içinde pembe renkli ilaçlar damar yoluyla onlara verilmektedir (s. 53). Hastalar için hastanede özel sağaltım metotları da uygulanmaktadır. Jeanne için ona daha fazla görev vermek ve onun daha fazla zamanını almak yönündeki 
hemşire Vigdis'in ordera tuttuğu notlar, benzeri bir sağaltımın örneği olup bir taraftan da heterotopyada bireyin nasıl kendinden uzaklaştırılmaya çalışıldığını da göstermektedir. Dr. Gunnar'ın Afîfe'den gece sabaha kadar yazmasını istediği beş yüz sayfa yazı da aynı sağaltım yönteminin bir parçasıdır. Ayrıca hastaların odası sürekli dinlenmekte ve rahatsızlıkları arttığında hemşireler ve doktorlar koşarak gelip hastaya müdahale edebilmektedirler.

Hastanede kalan hastalar sürekli baskı altında olduklarının farkındadırlar ve bu durumdan rahatsızdırlar. Normalleştirilmek istemeseler de normalleştirme süreci içine farkında olmadan dâhil oldukları için pişmandırlar. Normallerin her gün oynadığ1 'MIŞ GİBI'' oyununu oynamak, normalmiş gibi davranmak, anormal/ öteki olmadıklarını kanıtlamak, kendi seçtikleri isimlerini gizlemek istemezler. Zamanla hastanedeki sürekli ve isimsiz baskı ortamının sevkiyle aralarında bir ajan olduğuna bile inanmaya başlarlar. Gizli toplantılar yaparlar, kendi aralarında örgütlenirler. Hastanede sürekli binadan aşağıya birilerinin düşmesine benzer seslerin gelişi ve hastanedeki hastaların birer birer ortadan kaybolması hastaların korkularını arttırır. Heterotopya gittikçe 1ssızlaşmakta, onun korkutucu iç yüzü ötekileri eyleme geçmeye sevk etmektedir. Sonunda beraberce hastaneden kaçmaya karar verirler. Ütopyalar genellikle dünyadan kaçarak sığınılan edebî korunaklardır. Aynı şekilde Fantolt'taki hastalar da hastaneden kaçarak Balık İzlerinin Sesi adındaki bir ütopya adasına sı̆ğınırlar. Ütopya sadece kaçış eylemiyle değil sığınma eylemiyle de ilgilidir. Bu noktada kaçışın nihayet bulduğu sığınak tanımlaması ütopyalar için en doğru tanımlama olacaktır.

\subsection{Sanrısal Ütopyaya Kaçış}

Afîfe ve arkadaşlarının en son yaptıkları toplantıda Romain Gary, normallerden kurtulmak için ötekilerin onlarda bulunmayan yegâne özelliklerini kullanmaları gerektiğini söyler, bu özellik de düş gücüdür. Böylece ötekiler normallerin kabul edemeyeceği, yanına bile yaklaşamayacağ 1 soyutun dairesine sı̆̆ınmaları gerektiğine karar verirler. Bir oyun oynayacaklardır, bu oyun "bir çeşit halüsinasyon oyunu olaca[ktır]", "yanulsamalar ve sanrllar"dan oluşacaktır ve "Neşeli bir ölüm [e]" böylece beraberce koşacaklardır (s. 129). Somut gerçekteki heterotopyadan soyuta kaçış, sığınma; ötekiler adına simgesel bir ölümle eserde eşitlenmektedir. Kararın alınması ardından hastalar hastaneden varsanılarında topluca kaçarlar. Bu kaçış fantastik bir yolculuk şeklinde gerçekleşir. Vardıkları ütopya adasında sadece kendileri gibi ötekiler vardır. Ben'in kurduğu heterotopyaya seçerek yerleştirdikleri ötekiler, ütopyalarında da ben'in kendi seçtikleriyle oluşturduğu ve böylece sınırlarını belirlediği daireden, heterotopyadan uzaklaşamamaktadırlar.

Söz konusu ütopya adası, tasarımı açısından diğer ütopyalardan ayrılmaktadır çünkü öncelikle bir kişinin hayallerine değil bir topluluğun ortak sanrılarına, 
varsanılarına dayanmakta ve bu varsanılar heterotopyanın kazandırdığ kimliğin doğal bir sonucu olarak tezahür etmektedir. Heterotopyada doğan, heterotopyadan doğan bir ütopya olarak diğer ütopyaların hayallere dayanan yapıs1nın aksine, hastalıklı bir bilincin/bilinçlerin tasarımları mahiyetinde bir sanrısal, varsanılara dayalı ütopik ada tasarımı ortaya çıkmaktadır. ${ }^{34}$ Ayrıca heterotopyanın ben'i de içine çekme, yutma eğilimi özellikle bu sanrısal ütopik ada tasarımı dolayısıyla rahatlıkla görülebilmektedir. Normallerin hastanedeki temsilcisi konumundaki Dr. Günnar ve hemşire Vigdis gerek sanrısal ütopik adaya gidişte gerekse ütopya adasında ötekilerle birlikte yer almaktadırlar. Öteki'nin sadece ötekilerden oluşan adaya ben'i kendine dönüştürerek kabulü, ideal ben ütopyalarının kurallarının söz konusu sanrısal ütopya adasında da benzeri şekilde işletildiğini; tek tipleştirici, türleştirici, türe dönüştürücü benimseyişin kabul edildiğini, esas addedildiğini göstermektedir.

Hastaneden ayrılmadan önceki (heterotopyadaki) son gece düzenlenen partiye benzeyen ütopya adasındaki partinin ardından Afîfe, kendisi için Romain'in özel olarak seçtiği evin en üst katındaki hegzagonal odasına çıkarak uyur. Bu uykuyla sanrısal ütopya anlatımı da son bulur. Buradaki hegzagonal yap1 panoptik sistemin merkezindeki kuleyi çağrıştırmaktadır. Normallerin heterotopya içine inşa ettiği kapanma mekânının hegzagonal yapısına benzer bir odaya giren Afîfe'nin aynı hegzagonal yapıya sahip bir arı kovanının merkezine yerleşen kraliçe arı gibi, ötekilerden oluşan yeni bir koloninin habercisi, öncüsü gibi davrandığ görülür. Heterotopyanın merkezindeki ben'in tek kalesinin, gözetim evinin de böylece ben'in elinden alınmış olduğu varsayımından hareket edilecek olursa öteki'nin ütopyasının da ben'in ütopyasından farklı olmadığı görülecektir. Ayrıca bu sanrısal ütopyanın negatif yansımasıyla dünya da bir distopyaya dönüşmüş gibi romanın sonunda anlatılmaktadır. Yazar, sanrısal ütopik ada tasarımını kuran ötekilerin yokluğunda ötekisiz bir dünyada normallerin nasıl bir felakete doğru yaklaştıklarının farkında bile olmadıkları son gecelerini geçirdiklerini söyler. Gecenin sonunda okyanustan sahile vuran binlerce kılçıksız balık ölüsü metaforuyla ötekisiz bir dünyanın ben'in varlığını da tartışmalı hâle getireceği dile getirilmekte ben ve öteki diyalektiğinin devamının gerekliliği didaktik biçimde romanın mesaj diline yüklenmektedir.

34 "Ütopik sanrısal ada tasarımı" konusu bu makale sınırları içinde değerlendirilemeyecek kadar geniş bir konu olup ayrı bir makalede ele alınacaktır. 


\section{Sonuç}

Buket Uzuner'in Balık İzlerinin Sesi adlı romanı bir ütopyadan doğan kapatma mekânı olarak heterotopyanın özelliklerinin hem içten hem de dıştan anlatımını beraberce içermesi, heterotopyanın ütopyadan doğan vasıflarının tespiti, heterotopyanın genel karakteristik özelliklerinin anlatımı, ben-öteki diyalektiği bağlamında heterotopyanın öteki'ne biçilen rolü somutlaştırma girişimi şeklinde okunmasını ve heterotopyaların önceki ütopyalardan farklı olarak sanrısal ütopyalar ve distopyalar doğurmasını örneklemesi, öteki'nin anlatımının genelde esas alınması açılarından önemli bir eserdir. Eser öteki'nin ben'e bağlılığının içselleştirildiği bir düşün sisteminin söylemlerinin genel tekrarını yapması; öteki'ni ben'e, ben'i öteki'ne mahkûm edişiyle öteki'nin mahkûmiyetinden tek kurtuluş çaresini bir sanrısal ütopyaya sığınmakta gösterişi; ben-öteki ilişkisinin ötekine dair söylem üzerine geliştirdiği düşüncelerin didaktik kabule dayalı içselleştirilmesini bir umutsuzluk sarmalında çoğaltarak imkânsızlaştırması dolayısıyla heterotopyaların umut kırıcı, öteki'nin ötekiliğini keskinleştirici yapısını gözler önüne sermektedir.

Batı edebiyatında ütopyalar bağlamında değerlendirilen Hermann Hesse'nin Boncuk Oyunu $u^{35}$ 'ndaki ütopya anlatımı içinde doğmaya başlayan bir heterotopya örneği olarak Kastalya, heterotopyanın iç dinamiklerinin tüm diş sistemi bir heterotopyaya çevirmesi durumunda yaşanacakları kurgusal bir dille örnekleyen George Orwell'in 1984 adlı distopyasındaki Okyanusya, heterotopya ile ütopya ve distopya arasındaki yakın ilişkiyi kabul eden, benimseyen yazarların eserlerindeki heterotopyalardır. Kastalya ${ }^{36}$, ütopya içinde yeşermeye başlayan heterotopya fikrini örneklerken Okyanusya gelecekteki heterotopya cehennemine distopya içinde dikkat çeker. Buket Uzuner'in romanı, bir heterotopyanın ütopya fikrinden doğuşunu, heterotopyanın yapısını ve heterotopya fikrinin sonunda insanı sürükleyeceği heterotopyalardan doğan sanrısal ütopyayı/distopyayı beraberce anlatması, bu yönde bir yaklaşımı tezle sunması kısacası bir heterotopyanın (Fantolt) anatomisini keşfe çıkışı açısından önem arz etmekte ve Türk edebiyatındaki diğer pek çok romandan bu yönüyle ayrılmaktadır.

35 Hermann Hesse, Boncuk Oyunu, Çev. Kâmuran Şipal, 9. Bs., İst., YKY, 2013.

36 Gürsel Aytaç, roman üzerine incelemesinde Fantolt'u "dünyadan yalıtılmış haliyle" Kastalya'ya benzettiğini söylemekle yetinmekte Kastalya'nın heterotopyalara benzerliği noktasında herhangi bir tespitte bulunmamaktadır. Gürsel Aytaç, Çăgdaş Türk Romanı Üzerine İncelemeler, 3. Bs., Ankara, Doğu-Batı Yay., 2012, s. 407. 


\section{Kaynakça}

Aytaç, Gürsel, Çağdaş Türk Romanı Üzerine Incelemeler, 3. bs., Ankara, Doğu-Batı Yayınları, 2012.

Bachelard, Gaston, Mekânın Poetikası, çev. Alp Tümertekin, İstanbul, İthaki Yayınlar1, 3. bs., 2013.

Baudrillard, Jean, Simülakrlar ve Simülasyon, çev. Oğuz Adanır, 6. bs., Ankara, Doğu Batı Yayınları, 2011.

Bauman, Zygmunt, Bireyselleşmiş Toplum, çev. Yavuz Alogan, 2. bs., İstanbul, Ayrıntı Yayınları, 2011.

bs., İstanbul, Ayrıntı Yayınları, 2014.

, Küreselleşme: Toplumsal Sonuçları, çev. Abdullah Yılmaz, 5.

Bentham, Jeremy vd, Panoptikon: Gözün İktidarı, çev. Barış Çoban, Zeynep Özarslan, İstanbul, Su Yayınları, 2008.

Çetin, Nurullah, Roman Çözümleme Yöntemi, 4. bs., Ankara, Edebiyat Otağ1 Yayınlar1, 2006.

Devellioğlu, Ferit, Osmanlıca-Türkçe Ansiklopedik Lûgat: Eski ve Yeni Harflerle, 10. bs., Ankara, Aydın Kitabevi, 1992.

Foucault, Michel, "Başka Mekânlara Dair", Özne ve İktidar: Seçme Yazılar, İstanbul, Ayrıntı Yayınları, 2011.

, Hapishanenin Doğuşu: Gözetim Altında Tutmak ve Cezalandırmak, çev. Mehmet Ali K1lıçbay, 5. bs., Ankara, İmge Kitabevi, 2013.

Gariper, Cafer-Küçükcoşkun, Yasemin, “Buket Uzuner'in Kişilikler Oyunu ve Fantastik-Ütopik Dünyası: Balık İzlerinin Sesi Romanı”, Türkbilig, sayı 14, 2007.

Göktürk, Akşit, Ada: İngiliz Yazınında Ada Kavramı, 3. bs., İstanbul, YKY, 1997.

Harvey, David, Umut Mekânlarl, çev. Zeynep Gambetti, 2. bs., İstanbul, Metis Yayınları, 2011.

Hesse, Hermann, Boncuk Oyunu, çev. Kâmuran Şipal, 9. bs., İstanbul, YKY, 2013.

http://medical-dictionary.thefreedictionary.com/heterotopia (27.12.2014)

More, Thomas, Utopia, çev. Sabahattin Eyüboğlu, Vedat Günyol, Mina Urgan, 18. bs., İstanbul, Türkiye İş Bankası Yayınları, 2014.

Orwell, George, Bin Dokuz Yüz Seksen Dört, çev. Nuran Akgören, 19. bs., İstanbul, Can Yayınları, 2008. 
Uzuner, Buket, Balık İzlerinin Sesi, 22. bs., İstanbul, Everest Yayınları, 2012. Uzuner, Buket, Bir Siyah Saçlı Kadının Gezi Notları, İstanbul, Everest Yayınları, 2010.

Yardımcı, Sibel, “Canavar: Kültüralizm Ne Zamandı?”, Çăgdaş Sanat ve Kültüralizm: Kimlik ve Estetik, der. Ali Artun, çev. Tuncay Birkan, Nursu Örge, Elçin Gen, İstanbul, İletişim Yayınları, 2013. 
